\title{
2x2 Başarı Yönelimleri Ölçeği (Revize Formu): Geçerlik ve Güvenirlik Çalışması
}

\begin{abstract}
Serhat ARSLAN*
Ahmet AKIN**

Öz

Bu araştırmanın amacı 2x2 Başarı Yönelimleri Ölçeği revize formunu (Elliot \& Murayama, 2008) Türkçe'ye uyarlamaktır. Araştırma 450 üniversite öğrencisi üzerinde yürütülmüştür. Ölçeğin iç tutarlılık güvenirlik katsayıları, öğrenme-yaklaşma yönelimi alt boyutu için.72, öğrenmekaçınma yönelimi ilgi alt boyutu için. 68, performans-yaklaşma yönelimi alt boyutu için. 62 ve performans-kaçınma yönelimi alt boyutu için .69 olarak bulunmuştur. Ölçeğin madde toplam korelasyon katsayıları .50 ve .70 arasında sıralanmaktadır. Doğrulayıcı faktör analizinde 12 maddeden oluşan 4 boyutlu modelin (öğrenme-yaklaşma yönelimi, öğrenme-kaçınma yönelimi, performans-yaklaşma yönelimi ve performans-kaçınma yönelimi) iyi uyum verdiği görülmüştür. Doğrulayıcı faktör analizinde dört boyutlu modelin iyi uyum verdiği görülmüştür $\left(\mathrm{x}^{2}=\right.$ 172.08, $\mathrm{sd}=48, \mathrm{RMSEA}=.076, \mathrm{NNFI}=.97, \mathrm{NFI}=.98, \mathrm{CFI}=.98, \mathrm{IFI}=.98, \mathrm{RFI}=.96, \mathrm{GFI}=.94, \mathrm{SRMR}=$ .048). Bu sonuçlar 2x2 Başarı Yönelimleri Ölçeği Revize Türkçe formunun geçerli ve güvenilir bir ölçme aracı olduğunu göstermektedir.
\end{abstract}

Anahtar Kelimeler: Başarı yönelimleri, geçerlilik, güvenirlik.

\section{The Validity and Reliability Study of $2 \times 2$ Achievement Goal Orientations Scale (Revised Form)}

\begin{abstract}
The aim of this research is to examine the validity and reliability of the revised Turkish version of the 2x2 Achievement Goals Questionnaires (Elliot \& Murayama, 2008). The sample of this study consisted of 450 university students. Cronbach alpha internal consistency reliability coefficients were .72 for learning-approach subscale, .68 for learning-avoidance subscale, .62 for performance-approach subscale, and .69 for performance-avoidance subscale. Results showed that corrected item total correlation coefficients of the scale ranged from .50 to .70 . Results of confirmatory factor analysis demonstrated that the four-dimensional model was well fit $(\mathrm{x} 2=$ 172.08, $\mathrm{df}=48, \mathrm{RMSEA}=.076, \mathrm{NNFI}=.97, \mathrm{NFI}=.98, \mathrm{CFI}=.98, \mathrm{IFI}=.98, \mathrm{RFI}=.96, \mathrm{GFI}=.94, \mathrm{SRMR}=$ .048). Overall findings demonstrated that Turkish version of the Achievement Goals Questionnaire had adequate validity and reliability scores.
\end{abstract}

Keywords: Achievement goals, validity, reliability.

\footnotetext{
* Yrd. Doç. Dr., Sakarya Üniversitesi Eğitim Fakültesi, serhatarslan@sakarya.edu.tr

** Doç. Dr., Sakarya Üniversitesi Eğitim Fakültesi, aakin@sakarya.edu.tr
} 


\section{GİRIŞ}

Başarı yönelimleri yaklaşımı, Dweck (1986), Nicholls (1984), Ames (1984) ve Maehr'in (1983) başarı hedeflerine ulaşmak isteyen bireylerin yetkinlik düzeylerinde bulunması gereken özellikleri inceledikleri çalışmalar ile başlamıştır. Başarı yönelimleri, bireyin yalnızca başarı görevlerinin peşinden gitme amacını içermez, ayrıca insanların bir hedefe ulaşmadaki başarılarını değerlendirirken kıstas aldığı belli bir standardı yansıtır (Ames, 1992). Yapılan çalışmalarda başarı yönelimlerinin alt boyutları; öğrenme ve performans yönelimi olarak tanımlanmıştır (Elliot, 1999; Pintrich, 2000). Öğrenme yönelimi, bireyin bilgiyi içselleştirmesi olarak nitelendirilmekte ve bilginin hakimiyetini kazanmaya ait kişisel bir isteğe dayanmaktadır. Buna karşın performans yönelimi, bireyin performans beklentilerini yerine getirme veya emsallerini nispeten geçme amacına dayanmaktadır (Elliot, 1999; Harackiewicz, Brown, \& Elliot, 1998; Rawsthorne \& Elliot, 1999). Başarı yönelimleri teorisi, başarı hedeflerini operasyonel olarak bir yetkinlik kurgusunun mekanizmasıyla, öğrenicinin kendi performans standardını belirlemesiyle açıklamaktadır. Bu standartlar kesin (görevin kendi gerekliliklerine dayanan), içsel (kişinin geçmiş kazanımına veya maksimum potansiyel kazanımına dayanan) veya normatif (diğerlerinin performansına dayanan) (Elliot, 1999; Elliot \& McGregor, 2001) olabilmektedir.

Ayrıca başarı yönelimleri, yetkinliğe doğru kişisel bir yöneltimden (hakimiyet veya performans) ve başarıya yönelik ilişkiden (yaklaşma veya kaçınma) ortaya çıkmaktadır. Başarı yönelimleri modeli yakın dönemde öğrenme-yaklaşma, öğrenme-kaçınma, performans-yaklaşma ve performans-kaçınma boyutlarını kapsayan 2x2 bir çerçeve olarak ele alınmıştır (Elliot \& McGregor, 2001). Başarı amacı literatürünü organize etmek üzere, hem
Elliot hem Pintrich öğrenme ve performans hedeflerini yaklaşma ve kaçınma versiyonlarıyla beraber sınıflandıran, kapsayıcı bir çerçeve önermiştir (Elliot \& McGregor, 2001; Pintrich, 2000). Öğrenme yönelimi, öğrencinin öğrenme sürecinde karşılaştığı eğitim içeriklerini tam anlamıyla içselleştirmesi ve konu alanlarına hakim olmasını içermektedir (Akın, 2006). Jagacinski ve Nicholls (1989) yapmış olduğu çalışmada, öğrenme yöneliminin öğrencilerin başarıyı göreve bağlı olarak tanımlamalarında ve gelişimlerini kendi referanslarına göre değerlendirebilmelerine olanak sağlayabileceği sonucuna ulaşmıştır. Performans yönelimi ise, öğrencinin sosyal karşılaştırmaya önem vermesi, çalışmalarını diğerlerini referans alarak ve onlardan daha iyi yapmaya çalışarak yerine getirmesi, daha zeki ve yetenekli görünmeye çalışması ve yeteneksiz görünmekten kaçınması gibi özellikleri yansıtır (Akın, 2006).

Yaklaşma-kaçınma yönelimi; bir yakınlaşma odağı bireyleri arzulanan sonuçları geliştirmeye çabalamasına yol açarken bir kaçınma odağı da bireyleri istenmeyen sonuçlardan kaçınmaya çabalamasını sağlamaktadır. Öğrenme-performans yönelimi ise ortaya çıkışından bu yana başarı motivasyonu araştırmasına temel oluşturmuştur. Öğrenme yönelimi geleneksel olarak sadece yaklaşma formunda kurgulanmış olsa da bireylerin bir görevi anlamamak veya üstünde hakimiyet kurmamaktan kaçınmaya çabaladığı durumlar oluşmaktadır. Öğrenme yönelimleri hem yaklaşma hem de kaçınma boyutlarında dışa vurulabilmektedir. Öğrenme-yaklaşımlı amaçlar öğrenmeye doğru olumlu bir yönelimin tüm unsurlarına işaret ederken, öğrenme-kaçınımlı amaçlar bazı olumsuz nitelikleri işaret etmektedir (Elliot \& McGregor, 2001). Performans-yaklaşımlı hedefler olumlu olarak görülmektedir çünkü performans geliştirmeye yönelik ilgi ortaya çıkmaktadır (Elliot, ve diğ., 1999). Performans-kaçınma 
yönelimi, sınav kaygısı gibi etkili korku unsurlarının varlığı (Elliot \& McGregor, 1999; McGregor \& Elliot, 2002) ve diğerlerine kıyasla yetersizlikten kaçınmaya odaklanma (Elliot, 1999) sebebiyle olumsuz bir çağrışıma sahip olmaktadır (Fryer \& Elliot, 2007).

Yapılan çalışmalarda, öğrenme yönelimleri bireyin sahip olduğu umut ve gururla ilişkili ve öğrenmedeki yüksek keyif alma seviyelerinin olumlu yordayıcıları olarak ele alınmaktadır. (Harackiewicz, Barron, Tauer, Carter, \& Elliot, 2000). Karababa, Oral ve Dilmaç'ın (2014) yapmış olduğu çalışmada, ergenlerde insani değerlerin öğrenme amaç yönelimini anlamlı olarak yordadığı sonucuna ulaşılmıştır. Diğer çalışmalarda öğrenme-yaklaşma yönelimi; matematiğe yönelik olumlu tutumlar (Akın, 2012), kararlılık (Akın, \& Arslan, 2014), akademik içsel kontrol odağı (Akın, 2010) ile pozitif ilişkili bulunmuştur. Öğrenme-kaçınma ve performans-kaçınma yönelimlerinin ise bu değişkenlerle negatif ilişkili olduğu saptanmıştır.

Araştırmacılara göre eğer bir öğretmen öğrencisinin başarı amaç oryantasyonunu bilirse o öğrencinin potansiyel başarısı hakkında bazı tahminlerde bulunabilir (Wentzel, 1989). Bir eğitimci olarak öğrencinin öğrenme, performans-yaklaşma veya performans-kaçınma amaç oryantasyonundan hangisini benimsediğini bilmek yararlı bir ön bilgidir. $\mathrm{Bu}$ çalışmanın amacı öğrencilerin başarı yönelimlerini değerlendirebilecek, Elliot ve Murayama (2008) tarafından geliştirilen 2x2 Başarı Yönelimleri Ölçeğinin geçerlik ve güvenirliğini incelemektir.

\section{YÖNTEM}

\section{Çalışma Grubu}

Araştırmanın çalışma grubu Sakarya Üniversitesinde öğrenim gören 450 öğrenciden oluşmaktadır. Öğrencilerin $71^{\prime} i$ sınıf öğret- menliği, 92'si okul öncesi öğretmenliği, 89'u matematik öğretmenliği, $98^{\prime}$ i fen bilgisi öğretmenliği ve 100 ü psikolojik danışmanlık ve rehberlik bölümlerinde öğrenim görmektedir. 260's1 kız, 190'ı erkek öğrenciden oluşan bu grubun yaş ortalaması 21. 2' dir.

\section{Veri Toplama Arac1}

2x2 Başarı Yönelimleri Ölçeği; Elliot ve Murayama (2008) tarafından geliştirilen bu ölçme aracı 12 maddeden ve öğrenme-yaklaşma yönelimi (3 madde), öğrenme-kaçınma yönelimi (3 madde), performans-yaklaşma yönelimi (3 madde) ve performans-kaçınma yönelimi (3 madde) şeklinde 4 alt ölçekten oluşmaktadır. Ölçeğin Cronbach alfa iç tutarlılık güvenirlik katsayıları; öğrenme-yaklaşma yönelimi için .84, öğrenme-kaçınma yönelimi için .87, performans yaklaşma yönelimi için .92, performans-kaçınma yönelimi için .94 olarak bulunmuştur. 5'li Likert (5:tamamen katılıyorum- 1:tamamen katılmıorum) tipi bir ölçme aracı olan 2x2 Başarı Yönelimleri Ölçeğinin faktör yükleri. 73 ile .93 arasında sıralanmaktadır. Bireyin hangi başarı yönelimini benimsediğini belirlemek için her bir alt boyuttan alınan toplam puanın o alt boyutun içerdiği madde sayısına bölünmelidir.

\section{İşlem}

Ölçeğin uyarlama çalışması için ölçeği geliştiren Andrew J. Elliot ile e-mail yoluyla iletişim kurulmuş ve ölçeğin uyarlanabileceğine ilişkin gerekli izin alınmıştır. 2x2 Başarı Yönelimleri Ölçeğinin Türkçeye çevrilme sürecinde öncelikle ölçek iyi derecede İngilizce bilen Rehberlik ve Psikolojik Danışma bölümünde görevli 3 öğretim üyesi tarafından Türkçeye çevrilmiş ve daha sonra bu Türkçe formlar tekrar İngilizceye çevrilerek iki form arasındaki tutarlılık incelenmiştir. Ardından eğitim bilimleri alanından 4 akademisyen elde ettikleri Türkçe formlar üzerinde tartışarak anlam ve dilbilgisi açısından gerekli düzeltmeleri yapmış ve Türkçe form elde edilmiştir. $2 \times 2$ 
Başarı Yönelimleri Ölçeğinin geçerlik çalışması olarak yapı geçerliği incelenmiştir. Yapı geçerliği için doğrulayıcı faktör analizi (DFA) yapılmıştır. 2x2 Başarı Yönelimleri Ölçeğinin güvenirliği iç tutarlık, madde analizi ise düzeltilmiş madde toplam korelasyonuyla incelenmiştir. Geçerlik ve güvenirlik analizleri için SPSS 13.0 ve LISREL 8.54 (Jöreskog \& Sorbom, 1996) programları kullanılmıştır.

\section{BULGULAR}

\section{Madde Analizi ve Güvenirlik}

2x2 Başarı Yönelimleri Ölçeği maddelerinin ayırt etme gücünü belirlemek amacıyla madde analizi yapılmıştır. Yapılan analiz sonucunda, ölçeğin düzeltilmiş madde toplam korelasyon katsayılarının .50 ile .70 arasında siralandığ görülmüştür. Bulgular Tablo 1'de görülmektedir.

Tablo 1. 2x2 Başarı Yönelimleri Ölçeğinin Düzeltilmiş Madde Toplam Test Korelasyonları

\begin{tabular}{llll}
\hline Madde No & $\bar{X}$ & $S_{s}$ & $r_{j x}$ \\
\hline 1 & 3,73 & 1,09 & .53 \\
2 & 4,02 &, 88 & .60 \\
3 & 3,95 &, 87 & .63 \\
4 & 3,82 &, 92 & .50 \\
5 & 3,88 &, 87 & .56 \\
6 &, 87 & .61 \\
7 & 3,88 &, 99 & .67 \\
8 & 3,87 & 1,00 & .67 \\
9 & 3,81 &, 98 & .70 \\
10 & 3,84 &, 98 & .65 \\
11 & 3,80 & 1,00 & .65 \\
12 & 3,89 & 1,09 & .59 \\
\hline
\end{tabular}

2x2 Başarı Yönelimleri Ölçeğinin iç tutarlılık güvenirlik katsayıları, öğrenme-yaklaşma yönelimi alt boyutu için .72, öğrenme-kaçınma yönelimi alt boyutu için .68, performans- yaklaşma yönelimi alt boyutu için .62 ve performans-kaçınma yönelimi alt boyutu için .69 olarak bulunmuştur.

Tablo2. 2x2 Başarı Yönelimleri Ölçeğinin \%27'lik alt-üst grup farkına ilişkin t değerleri, ortalamalar ve standart sapmalar

\begin{tabular}{|c|c|c|c|c|c|}
\hline \multirow[t]{2}{*}{$\begin{array}{l}\text { Madde } \\
\text { No }\end{array}$} & \multicolumn{2}{|c|}{$\begin{array}{c}\text { \%27'lik üst grup } \\
n(121)\end{array}$} & \multicolumn{2}{|c|}{$\begin{array}{c}\text { \%27'lik alt grup } \\
n(121)\end{array}$} & \multirow[b]{2}{*}{$t$} \\
\hline & $\bar{X}$ & $S_{S}$ & $\bar{X}$ & Ss & \\
\hline 1 & 4,51 & 0,74 & 2,97 & 0,68 & $13,16^{* * *}$ \\
\hline 2 & 4,73 & 0,48 & 3,37 & 0,77 & $15,27^{* * *}$ \\
\hline 3 & 4,64 & 0,56 & 3,32 & 0,76 & $15,32^{* * *}$ \\
\hline 4 & 4,60 & 0,57 & 3,30 & 0,74 & $15,15^{* * *}$ \\
\hline 5 & 4,61 & 0,50 & 3,39 & 0,81 & $14,08^{* * *}$ \\
\hline 6 & 4,62 & 0,52 & 3,31 & 0,79 & $15,22^{* * *}$ \\
\hline 7 & 4,74 & 0,55 & 3,14 & 1,01 & $15,28^{* * *}$ \\
\hline 8 & 4,69 & 0,46 & 2,88 & 1,01 & $17,92^{* * *}$ \\
\hline 9 & 4,74 & 0,47 & 2,94 & 0,93 & $18,92^{* * *}$ \\
\hline 10 & 4,61 & 0,67 & 2,87 & 0,94 & $16,47^{* * *}$ \\
\hline 11 & 4,80 & 0,44 & 3,02 & 0,98 & $18,23^{* * *}$ \\
\hline 12 & 4,80 & 0,51 & 2,88 & 1,05 & $18,09^{* * *}$ \\
\hline
\end{tabular}


Ölçekten alınan toplam puana göre alt ve üst \%27'lik grupların, madde puanlarının ortalamalarının karşılaştırılması için yapılan bağımsız $t$-testi sonucuna göre $t$ değerlerinin anlamlı $(\mathrm{p}<0.001)$ olduğu görülmüştür.

\section{Yapı Geçerliği}

Dört boyutlu model için uygulanan doğrulayıcı faktör analizinde uyum indeksi değerleri $x 2=$ 172.08, $\mathrm{sd}=48, \mathrm{RMSEA}=.076, \mathrm{NNFI}=.97, \mathrm{NFI}=$ $.98, \mathrm{CFI}=.98, \mathrm{IFI}=.98, \mathrm{RFI}=.96, \mathrm{GFI}=.94, \mathrm{SRMR}=$ .048 olarak bulunmuştur. Doğrulayıcı faktör analizine ait faktör yükleri Şekil 1'de gösterilmiştir.

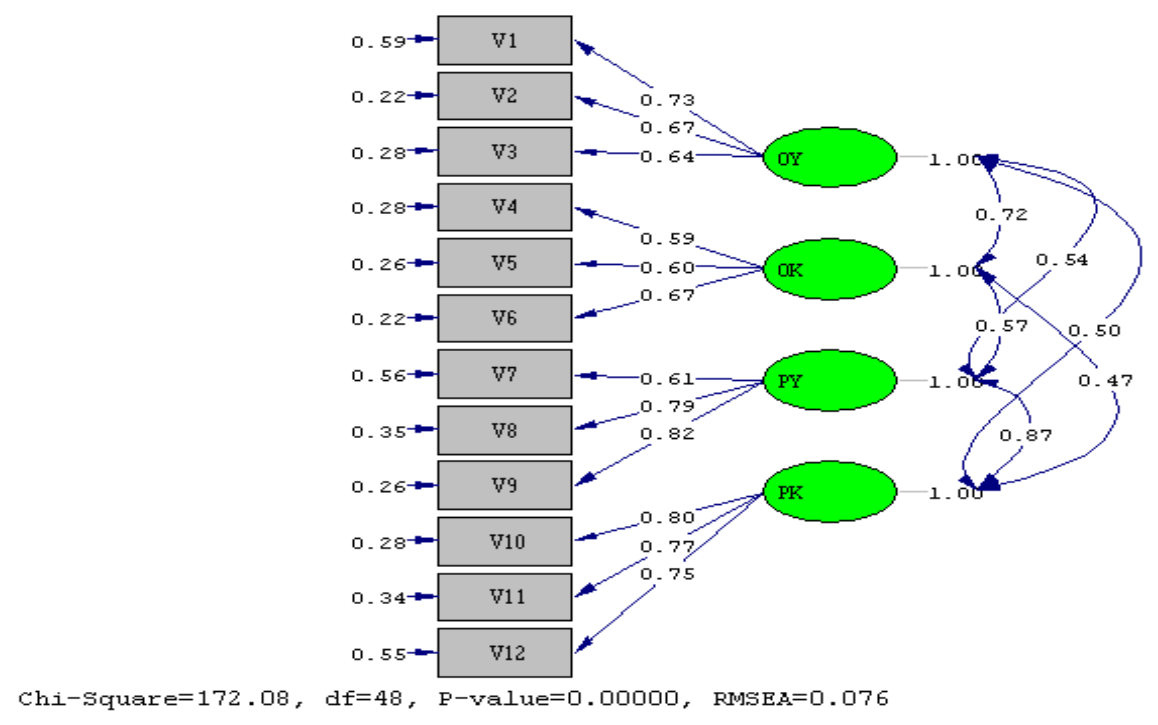

Şekil 1. Doğrulayıcı faktör analizine ait faktör yükleri

\section{TARTIŞMA}

Bu çalışmada 2x2 Başarı Yönelimleri Ölçeği'nin Türkçeye uyarlanması ve Türkçe formun geçerlik ve güvenirliğinin incelenmesi amaçlanmıştır. Ölçeğin yapı geçerliği için orijinal formda bulunan dört faktörlü yapısının doğrulanması amacıyla doğrulayıcı faktör analizi uygulanmıştır. Doğrulayıcı faktör analizinde sınanan modelin uyum yeterliğini belirlemek için pek çok uyum indeksi kullanılmaktadır. GFI, CFI, IFI ve NFI indeksleri için kabul edilebilir uyum değeri .90 ve mükemmel uyum değeri 95 olarak kabul edilmektedir (Hu \& Bentler, 1999; Marsh, Hau, Artelt, Baumert, \& Peschar, 2006). RMSEA için ise .08-.05 arası kabul edilebilir uyum ve .05 altı mükemmel uyum değeri olarak kabul edilmektedir (Brown \& Cudeck, 1993;
Byrne \& Campbell, 1999). $x^{2} /$ sd değerinin ise 23 arasının kabul edilebilir, 0-2 arasının ise iyi uyum değeri olarak kabul edilmektedir. Doğrulayıcı faktör analizi sonuçlarına göre uyum indekslerinin kabul edilebilir olduğu ve uyum değerleri dikkate alındığında ölçeğin dört faktörlü yapısının iyi uyum verdiği görülmüştür. Ölçeğin madde analizi için düzeltilmiş madde toplam korelasyonları sonuçları incelenmiştir. Düzeltilmiş madde toplam korelasyonları test maddelerinden alınan puanlar ile testin toplam puanı arasındaki ilişkiyi açıklar ve bu değerlerin pozitif ve yüksek olması bir ölçme aracındaki her bir maddenin benzer davranışları örneklediğini gösterir. Düzeltilmiş madde toplam korelasyonlarının .30 ve üzerinde olması yeterli kabul edilmektedir (Büyüköztürk, 
2010). Yapılan çalışma ölçeğin iç tutarlılık güvenirliğinin yeterli olduğunu göstermiştir. Ancak ölçeğin zaman içindeki güvenirliğini ölçmek için test tekrar-test çalışmasının yapılması ölçeğin güvenirlik özelliklerinin anlaşılmasına katkı sağlayabilir. Ayrıca, iç tutarlılık katsayıları orijinal ölçekten düşük çıkmasının nedeni olarak kültürel farlılıktan kaynaklanabileceği düşünülmektedir. Araştırma örnekleminin eğitim fakültesinde öğrenim gören öğrenci- lerle sınırlı olduğundan, başarı yönelimleri ölçeği için farklı örneklemler üzerinde yapılacak geçerlik ve güvenirlik çalışmaları oldukça önemlidir. Ayrıca, başarı yönelimleri ölçeğinin ölçüt bağıntılı geçerliğini belirlemek amacıyla, başarı yönelimleri yapısı ile ilişkili olabilecek eğitimsel yapıları değerlendiren ve geçerlik, güvenirliği kanıtlanmış ölçme araçları ile bu ölçek arasındaki ilişkiler incelenebilir.

\section{Kaynakça}

Akın, A. (2006). 2X2 Başarı Yönelimleri Ölçeği: Geçerlik ve güvenirlik çalışması. Sakarya Üniversitesi Eğitim Fakültesi Dergisi, 12, 1-13.

Akın, A. (2010). Achievement goals and academic locus of control: A structural equation modeling approach. Eurasian Journal of Educational Research, (10)38, 1-18.

Akın, A. (2012). Achievement goal orientations and math attitudes. Studia Psychologica, 54(3), 237-249.

Akın, A., \& Arslan, S. (2014). The relationships between achievement goal orientations and grit. Education and Science, 39(175), 267-274.

Ames, C. (1984). Achievement attributions and self-instructions in competitive and individualistic goal structures. Journal of Educational Psychology, 76, 478-487.

Ames, C. (1992). Classrooms: Goals, structures, and student motivation. Journal of Educational Psychology, $84,261-271$.

Brown, M., \& Cudeck, R. (1993). Alternative ways of assessing model fit. In: K. A. Bollen \& J. S. Long (Eds.), Testing structural equation models (s. 136-162). Beverly Hills, CA: Sage.

Büyüköztürk, Ş. (2010). Sosyal bilimler için veri analizi el kitabı. (11. Baskı), Ankara: Pegem Akademi Yayınları.

Byrne, B. M., \& Campbell, T. L. (1999). Cross-cultural comparisons and the presumption of equivalent measurement and theoretical structure: a look beneath the surface. Journal of Cross-Cultural Psychology, 30, 555-574.

Dweck, C. S. (1986). Motivational processes affecting learning. American Psychologist, 41, 1040-1048.

Elliot, A. J. (1999). Approach and avoidance motivation and achievement goals. Educational Psychologist, 34, 149-169.

Elliot, A. J., \& McGregor, H.A. (2001). A 2 x 2 achievement goal framework. Journal of Personality and Social Psychology, 80, 501-519.

Elliot, A. J., McGregor, H. A., \& Gable, S. (1999). Achievement goals, study strategies, and exam performance: A mediational analysis. Journal of Educational Psychology, 91(3), 549-563.

Elliot, A. J., \& Murayama, K. (2008). On the measurement of achievement goals: Critique, illustration, and application. Journal of Educational Psychology, 100(3), 613-628.

Fryer, J. W., \& Elliot, A. J. (2007). Stability and change in achievement goals. Journal of Educational Psychology, 99 (4), 700-714.

Harackiewicz, J. M., Brown, K. E., \& Elliot, A. J. (1998). Rethinking achievement goals: When are they adaptive for college students and why? Educational Psychologist, 33(1), 1-21. 
Harackiewicz, J. M., Barron, K. E., Tauer, J. M., Carter, S. M., \& Elliot, A. J. (2000). Short-term and longterm consequences of achievement goals: Predicting interest and performance over time. Journal of Educational Psychology, 92(2), 316-330.

Hu, L. T., \& Bentler, P. M. (1999). Cutoff criteria for fit indexes in covariance structural analysis: Conventional criteria versus new alternatives. Structural Equation Modeling, 6, 1-55.

Joreskog, K. G., \& Sorbom, D. (1996). LISREL 8 referenceguide. Lincolnwood, IL: ScientificSoftware International.

Karababa, A., Oral, T., \& Dilmaç, B. (2014). Ergenlerin başarı amaç yönelimlerini yordayan değişkenlerden biri olarak: İnsani değerler. Değerler Ĕ̆itimi Dergisi, 12(27), 165-186.

Maehr, M. L. (1983). On doing well in science: Why Johnny no longer excels; why Sarah never did. In S. G. Paris, G. M. Olson, \& H. W. Stevenson (Eds.), Learning and motivation in the classroom (pp. 179210), Hillsdale, NJ: Erlbaum.

Marsh, H. W., Hau, K. T., Artelt, C., Baumert, J., \& Peschar, J. L. (2006). OECD's brief self-report measure of educational psychology's most useful affective constructs: Cross-cultural, psychometric comparisons across 25 countries. International Journal of Testing, 6(4), 311-360.

McGregor, H.A., \& Elliot, A.J. (2002). Achievement goals as predictors of achievement-relevant processes prior to task engagement. Journal of Educational Psychology, 94 (2), 381-395.

Nicholls, J. G. (1984). Achievement motivation: Conceptions of ability, subjective experience, task choice, and performance. Psychological Review, 91, 328-346.

Pintrich, P. R. (2000). An achievement goal theory perspective on issues in motivation terminology, theory, and research. Contemporary Educational Psychology, 25, 92-104.

Rawsthorne, L. J., \& Elliot, A.J. (1999). Achievement goals and intrinsic motivation: A meta-analytic review. Personality and Social Psychology Review, 3(4), 326-344. 


\section{Extended Summary}

\section{Introduction}

The achievement goal orientation approach has begun with the studies of Dweck (1986), Nicholls (1984), Ames (1984), and Maehr (1983) who investigated the necessary features of individuals, who aims to reach achievement goals, in terms of competence level. Achievement goal orientations include not only the aim of individuals in terms of following their achievement duties but also they reflect a certain standards that individuals put while evaluating their success in the process of reaching a goal (Ames, 1992). Researches defined two contrasting achievement goals as learning goals and performance goals (Elliot, 1999; Pintrich, 2000). Learning goals are described as individual's internalizing the knowledge. In addition, they are based on an individual desire to achieve dominance of the knowledge. On the other hand, performance goals are based on the aims of the individual in terms of fulfilling performance expectation or going their counterparts one better (Elliot, 1999; Harackiewicz, et al., 1998; Rawsthorne \& Elliot, 1999). The learning and performance goals may increase the person's internal interest to the subject in learning- teaching process (Harackiewicz, et al., 1998). Achievement Goal Orientations Theory makes the operational definition of the goal orientations with a construct mechanism of the competence, and students' determining their own performance standards. These standards can be exact (based on the duty's own necessities), intrinsic (based on individual's past gains or gaining maximum potential) or normative (based on others' performance) (Elliot, 1999; Elliot \& McGregor, 2001). Besides, achievement goal orientations are unique to a learning situation, and arise from a personal orientation to the competence (dominance or performance) and from a relation towards the success. Recently, achievement goal orientation model has been shown as $2 \times 2$ frame that includes learning-approach, learning-avoidance, performance-approach, and performance-avoidance. (Elliot \& McGregor, 2001). The learning goals include student's internalization of all education contents in learning process and having full knowledge of the topics (Akın, 2006). The aim of the present study is to investigate the reliability and validity of the $2 \times 2$ Achievement Goal Orientations Scale that was developed by Elliot and Murayama (2008) and that is able to evaluate students' achievement goals.

\section{Method}

Participants: The sample of the current study is composed of 450 students who are studying at Sakarya University. 260 of the participants are female and 190 of them are male and their mean age is 21. 2.

\section{Data Collection Tools:}

$2 \times 2$ Achievement Goal Orientations Scale; This instrument was developed by Elliot and Murayama (2008) and includes 12 items and 4 subscales: learning-approach ( 3 items), learning-avoidance ( 3 items), performance-approach ( 3 items) and performance-avoidance ( 3 items). The Cronbach Alpha coefficients of internal consistency were found as .84 for learning-approach, .87 for learning- avoidance, .92 for performance-approach, and .94 for performance-avoidance. Factor loadings of $2 \times 2$ Achievement Goal Orientations Scale ranged from .73 to .93 and each response is made on a five-point Likert scale anchored by "strongly agree (5)" and "strongly disagree (1)". In order to determine which goal orientations a student adopts, the total score of the each subscale should be divided by total item number in that subscale. 


\section{Procedure}

For the adaptation of the scale, necessary permission was taken via e- mail from Andrew J. Elliot who developed the scale. In the process of Turkish translation of the $2 \times 2$ Achievement Goal Orientations Scale, the scale was translated into Turkish by 3 academicians, being excellent in English, in Psychological Counseling and Guidance department. Then this form was translated into English again and the consistency between two forms was examined.

\section{Results and Discussion}

Cronbach alpha internal consistency reliability coefficients were .72 for learning-approach subscale, .68 for learning-avoidance subscale, .62 for performance-approach subscale, and .69 for performanceavoidance subscale. The results showed that corrected item total correlation coefficients of the scale ranged from .50 to .70. Confirmatory factor analysis was conducted for four-dimensional model and fit indexes were as follows: $x^{2}=172.08, \mathrm{df}=48, \mathrm{RMSEA}=.076, \mathrm{NNFI}=.97, \mathrm{NFI}=.98, \mathrm{CFI}=.98$, IFI= .98, RFI $=.96$, $\mathrm{GFI}=.94, \mathrm{SRMR}=.048$. Present study aims to adapt $2 \times 2$ Achievement Goal Orientations Scale (revised form) into Turkish and to investigate the reliability and validity of Turkish form. For the construct validity of the scale, in order to confirm four dimensional model of the original form, confirmatory factor analysis was conducted. In confirmatory factor analysis, several fit indices are used in order to determine how well the a priori model fits, or reproduces the data. Acceptable model fit for GFI, CFI, IFI and NFI are accepted as .90, and the best fit is accepted as .95 (Hu \& Bentler, 1999; Marsh, Hau, Artelt, Baumert, \& Peschar, 2006). For RMSEA, the acceptable model fit is accepted as .08-.05, and the best fit is accepted as less than .05 (Brown \& Cudeck, 1993; Byrne \& Campbell, 1999). For $x^{2} /$ sd value, the acceptable model fit is accepted as 2-3, and the best fit is accepted as 0-2. According to the results of confirmatory factor analysis, when considering the acceptable and the best model fits, the four dimensional structure of the scale showed a good fit. For item analysis of the scale, corrected item total correlation coefficients were examined. Corrected item total correlations refers the relationship between the scores from the items of the scale and scores from the total test. If this value is positive and high, this means that each item on the scale evaluates the similar behaviors. The .30 and higher corrected item total correlation coefficients are accepted as adequate. The current study shows that internal consistency of the scale is enough. 


\begin{tabular}{|}
$\mid \begin{array}{l}\text { Her sorunun karşısında bulunan; (1) Kesinlikle katılmıyorum (2) Katılmıyorum (3) } \\
\text { Kararsıım (4) Katılıorum ve (5) Kesinlikle katılıyorum anlamına gelmektedir }\end{array}$ \\
\hline 1 & Derste anlatılan konuları tamamen öğrenmeyi amaçlarım. & 1 & 2 & 3 & 4 & 5 \\
\hline 2 & Dersin içeriğini anlamak için gayret sarf ederim. & 1 & 2 & 3 & 4 & 5 \\
\hline 3 & $\begin{array}{l}\text { Ders süresi içerisinde mümkün olduğunca fazla şey öğrenmeyi } \\
\text { amaçlarım. }\end{array}$ & 1 & 2 & 3 & 4 & 5 \\
\hline 4 & Öğrenebileceğimden daha az şey öğrenmekten kaçınırım. & 1 & 2 & 3 & 4 & 5 \\
\hline 5 & Derste anlatılan konuları eksik öğrenmekten kaçıırım & 1 & 2 & 3 & 4 & 5 \\
\hline 6 & Bir konuyu olabildiğinden daha az öğrenmekten kaçınırım & 1 & 2 & 3 & 4 & 5 \\
\hline 7 & $\begin{array}{l}\text { Sinıfımdaki öğrencilere göre daha iyi performans göstermeyi } \\
\text { amaçlarım }\end{array}$ & 1 & 2 & 3 & 4 & 5 \\
\hline 8 & Diğer öğrencilere göre daha başarılı olmak için gayret ederim & 1 & 2 & 3 & 4 & 5 \\
\hline 9 & Diğer öğrencilerden daha iyi performans göstermeyi hedeflerim & 1 & 2 & 3 & 4 & 5 \\
\hline 10 & $\begin{array}{l}\text { Diğer öğrencilere göre başarısız görünmekten kaçınmaya } \\
\text { çalışırım }\end{array}$ & 1 & 2 & 3 & 4 & 5 \\
\hline 11 & $\begin{array}{l}\text { Diğer öğrencilerden daha kötü performans göstermemeye gayret } \\
\text { ederim }\end{array}$ & 1 & 2 & 3 & 4 & 5 \\
\hline 12 & $\begin{array}{l}\text { Diğer öğrencilerden daha kötü performans göstermemeyi } \\
\text { amaçlarım }\end{array}$ & 1 & 2 & 3 & 4 & 5 \\
\hline
\end{tabular}

